\title{
Media Consumption and Media Behavior of Contemporary Russian Youth as Constructs of Protest Identity
}

\section{Consumo de medios y comportamiento mediático de la juventud rusa contemporánea como construcciones de identidad de protesta}

\author{
Rashid Tazitdinovich Mukhaev \\ Plekhanov Russian University of Economics, Moscow, Russia \\ https://orcid.org/0000-0001-5686-8544 \\ Olga V. Shevchenko
}

Financial University under the Government of the Russian Federation, Moscow, Russia https://orcid.org/0000-0002-4883-603X

\section{Olga Dudina}

Financial University under the Government of the Russian Federation, Moscow, Russia https://orcid.org/0000-0001-6078-6365

Anatoly Vasilyevich Denikin

Financial University under the Government of the Russian Federation, Moscow, Russia https://orcid.org/0000-0002-2466-0703

Zoya Dmitrievna Denikina

Financial University under the Government of the Russian Federation, Moscow, Russia https://orcid.org/0000-0002-3119-1546

\section{*Correspondencia}

Email: rashid.mukhaev@bk.ru 


\section{Summary}

The relevance of the study topic is not only due to the very fact of the unauthorized gatherings in Russia on 24 and 31 January and 2 February, in which many young people, including minors, took part. The protests were inspired by the "Western mentors" of the Russian non-systemic opposition. It is equally important to understand the underlying reasons for the high involvement of young people in the protests in the context of the COVID-19 pandemic and the Western sanctions regime that has been running for seven years. The objective of the study is to analyze the causes, anatomy, technologies, and forms of protest representations of contemporary youth in Russia. The authors focus on the behavioral patterns of young people, the mechanism and content of which are now forming in the Internet space with the help of social networks. The means of recognizing social reality, markers of evaluation and its interpretation by the youth audience, and an algorithm for action are set by the Internet and social networks. Today, in many ways, Western digital giants determine the media consumption patterns, media behavior, and social practices of Russian youth. In this situation, it is important for the Russian state not to restrict access to the Internet but rather to shape a high political media culture among modern youth.

Keywords: Media Consumption, Media Behavior, Media Perception, Political Media Culture, Clip Identity.

\section{Resumen}

La relevancia del tema de estudio no se debe solo al hecho mismo de las reuniones no autorizadas en Rusia los días 24 y 31 de enero y 2 de febrero, en las que participaron muchos jóvenes, incluidos menores de edad. Las protestas fueron inspiradas por los "mentores occidentales" de la oposición no sistémica rusa. Es igualmente importante comprender las razones subyacentes de la alta participación de los jóvenes en las protestas en el contexto de la pandemia de COVID-19 y el régimen de sanciones occidental que ha estado funcionando durante siete años. El objetivo del estudio es analizar las causas, anatomía, tecnologías y formas de las representaciones de protesta de la juventud contemporánea en Rusia. Los autores se centran en los patrones de comportamiento de los jóvenes, cuyo mecanismo y contenido se están formando ahora en el espacio de Internet con la ayuda de las redes sociales. Los medios de reconocimiento de la realidad social, los marcadores de evaluación y su interpretación por parte de la audiencia juvenil, y un algoritmo de acción son establecidos por Internet y las redes sociales. Hoy, de muchas maneras, los gigantes digitales occidentales determinan los patrones de consumo de medios, el comportamiento de los medios y las prácticas sociales de la juventud rusa. En esta situación, es importante que el estado ruso no restrinja el acceso a Internet, sino que dé forma a una cultura mediática de alta política entre la juventud moderna.

Palabras clave: consumo de medios, comportamiento de los medios, percepción de los medios, cultura de los medios políticos, identidad del clip. 


\section{Introduction}

If we turn to the analysis of this issue in Western sources, their authors present the anatomy of this protest in an extremely tendentious and one-sided way as a conflict between "society and the existing regime" or, even more pompously, as a "revolution of the educated class" (Smirnov, 2021). The political bias of such assessments is unsurprising and obvious. It stems from the logic of the intensified competition between the US and Western Europe for the global hegemony of the "collective West", which dictates the urgency of undermining the unity of its main opponents - Russia and China - from within. Another thing is important. It should be objectively understood why the Anti-Corruption Foundation has been able to mobilize protest sentiments among such large segments of the youth audience so "easily and effortlessly". To attribute everything to the "immaturity" of young people and the "paid" nature of their participation is to simplify the problem and fail to see the underlying internal and external causes of the diffusion of protest identity among young people. This study hypothesizes that the former mechanism of cultural inheritance, in which the main role was played by socialization agents of the industrial society - family, school, and university - has collapsed, and the Internet and social networks have taken their place in the information society. They determine how reality is perceived, how it is interpreted, and the choice of action models for today's youth that are relevant to the media consumption strategies that are set by the American digital giants and that benefit their stakeholders.

\section{Methods}

The hypothesis is supported by several postulates that explain the radical changes in post-industrial society under the influence of the information and communication revolution. Firstly, the total use of media and mass media has resulted in the world becoming socially constructed. Our perceptions, experiences, beliefs, and behaviors are influenced by the media that surround us (Griffin, 2015). Traditional channels of interaction - newspapers, radio, television - are being replaced by the Internet, social networks, messengers, and smartphones. Along with them, the ways of influencing the mass consumer are changing: they are becoming visual, dynamic, and universal. The values and meanings constructed and transmitted through online communications extend to the global society. At the same time, while traditional media space is shaped and controlled by the state and the political elite, preserving its independence, Internet space exists by the rules of the market (supply and demand) and a large number of stakeholders are involved in its creation.

Secondly, the media's growing influence on the everyday life of the individual has led to an increase in the volume of communication, the targeting of communication strategies in accordance with consumer demands, and the diversity of technologies. It has become possible to talk about the mediatization of life, economics, politics, and the integration of social processes with mass media processes. Since a single message can influence the consciousness, behavior, and choices of a large number of people, media (i.e. their dependence on the media) and obedience to them becomes one of the main factors in the development of society. Under these conditions, media become tools for shaping almost all forms of culture and types of social practices. The virtualization and mediatization of social life have become a major factor in the formation of society's political culture, which has become a political-media culture. Political culture is understood as a set of attitudes, beliefs, and feelings about the political situation in the country at a given moment, which constructs the movements of subjects who act as part of political roles through the political system (Almond, Powell, 1966). In the Internet society, the mechanism of constructing attitudes, beliefs, and sentiments that give order and meaning to the political process and provide the initial preconditions and rules governing human behavior in the political system has changed radically.

Thirdly, the presence of various communication channels in the information age has led to the mediatization of politics, which has noticeably expanded the set of technologies for 
constructing media reality and society's political culture. According to J. Baudrillard, consumption of goods in a postmodern society occurs through the prism of signification (meaning) codes that allow interpreting reality, forming citizens' attitudes towards political processes, and exercising control over objects and individuals (Baudrillard, 1999). All objects of consumption, including politics and power, are symbolized and represented. Signification codes are transmitted to citizens in an attempt to disseminate the necessary agenda for gaining or retaining power. In doing so, the codes offer a structure of control and power that is much softer and at the same time more totalitarian than exploitation. "There are the substitution and loss of meanings, simulacra become more significant than traditional mental value preferences" (Shevchenko, 2011).

Thus, youth life orientations and the strategies and models of their implementation are constructs of media politics, which is a model of conducting politics by means of symbolic domination. All forms of social communication between different actors are influenced by the information that comes from the media according to the principle that "an event did not happen if it was not mentioned in the media". When building communication with target audiences, political technologists and bloggers first of all aim to form a code of perception through which a positive or negative attitude towards the phenomenon is formed.

Due to Internet technologies and social networks, a new mechanism of cultural transmission (transfer of social experience from one generation to another) is being constructed, in the work of which many stakeholders are involved, often pursuing selfish and destructive goals. This mechanism has created a new phenomenon - media behavior as a special "form of social behavior of an individual in different media contexts: media perception, media consumption, media production" (Rumin, 2010). Media behavior is a special kind of representation of an individual or an individual group, formed as a result of conscious or unconscious comprehension of information received from different media sources. An individual's media behavior consists of various components: cognition (knowledge) and skills (attention, perception, memorization, and learning) through which people select, use, and produce information; beliefs (an individual's personal attitude toward the world around $\mathrm{him} / \mathrm{her}$ ); attitude (a mental or nervous state of readiness to be active in a certain situation); behavioral intention (the desire to respond in a certain way to an object of a certain attitude).

The key features of media behavior are media consumption, media perception, and media production.

Media consumption is a set of media (entertaining or informational) used by an individual or group of individuals, including listening to the radio, reading the papers, watching television, and using the Internet. The modern stage of development of the information space is characterized by significant changes in the structure of consumption of communication channels. Moreover, some of them are fixed for several years, for example, changes in a segment of the press and radio broadcasting, others - literally before our eyes (the growth of popularity of the Internet editions and social media). The share of radio listeners and newspaper readers is steadily decreasing, but the number of those who read magazines and other specialized publications is increasing (Savin, 2013).

The technological revolution has had the most significant impact on the transformation of media consumption patterns. In the 20th century, society received information from television, radio, and newspapers without any feedback. This consumption model can be called "passive", where information is broadcast from one side only. However, with the appearance of the Internet, a modern person is becoming not only a media consumer but also a media producer. Two models of media consumption can be conventionally distinguished.

The mass audience model (1920s and late 1980s) assumes that the user chooses in favor of certain media, adapting their interests to an agenda defined by media professionals (the 
processes of its formation have the features of a two-way character due to the traditional targeting of the audience and consideration of their needs).

Modern youth audiences use the Internet audience model, which assumes that the user chooses certain media, but today's media are already adapting to the audience. For example, news feeds on social networks (Vkontakte, Facebook, etc.) are shaped according to a young user's hobbies. All media becomes "personified" - advertising is transformed based on user search: after a request in the search bar, one can see advertising banners on a site with previous requests. One can also recall streaming services on YouTube, where a person selects specific packages that generate a stream of new information based on requests. Thus, the user is both an active participant in communication and a creator of media content. For new media, it is not so much about reaching the audience as it is about engaging the media user and motivating them to take action. The modern Internet is a platform for generating new meanings, and social networks are places where these meanings are published, a kind of publication. In new media, a person changes their role smoothly and flexibly, acting as an audience, as an author, and as a coauthor. Today, the key task of new media is not the information product as such but the involvement of people, especially young people, in its creation, because the process of creating impressions is coming to the fore. An impression is the easiest to manipulate, especially in the context of permanent changes in technology and the constant creation of something new that will appeal to young people.

Media perception is the ways of perceiving "media reality", the feelings and thoughts of authors of media texts expressed in audiovisual, spatial, and temporal images. In today's society, more than $70 \%$ of the world's population lacks critical thinking. This means that the information that young people receive from the media is perceived by them as reliable. However, most players in the media sphere use the media for corporate or private interests for selfish purposes. For this reason, in many Western countries, there is a special discipline that is taught in schools and universities called "critical thinking". This type of thinking implies a person's ability to question the information they receive, sometimes even their own beliefs. However, it requires an "intellectual filter" that relies on knowledge. In modern society, dominated by virtual forms of personal representation, the former agents of socialization (family, school, and university) have also shifted to gaming models of learning with an emphasis on entertainment and spectacle. The temptation to acquire new impressions is driving today's youth and is shaping a clip thinking that is completely devoid of critical perception. In this context, today's youth are increasingly distrustful of information from the government media. This alienates part of the youth audience and creates a desire to oppose the state.

State and non-state media use similar techniques to influence the consciousness of young people:

1) Political PR is a system of activities aimed at building public loyalty to the state and NGOs through the effective implementation of the requests of target audiences. In a situation where the demands of young people remain unanswered by the authorities and civil society institutions, there are prerequisites for protest emotions. In this case, political PR is more like propaganda.

2) Political advertising is a conduit of ideas, a transmitter of images, symbols, and myths. Advertising allows the formation of attractive images of idols, projects of a desirable future, by means of which life benchmarks and target attitudes of young people are formed.

3) Message construction technologies are a set of tools and techniques for the authentic perception of the message desired by the communicator. Technology creates the message that the authorities or groups of interest are trying to convey to the youth audience. The message itself must be perceived correctly by the audience. The main technologies include: 1) agendasetting; 2) gatekeeping; 3 ) priming; 4) framing. 
4) Digital technologies are digital techniques for influencing young people to promote desired frames and ideas. Most Western leaders seek to promote their political ideas online. Television remains only as a means of maintaining their image (frequency of media mentions). Among the main technologies of the digital sphere are different types of targeting advertising, working with BigData, social networks, video hosting, etc., the creation of their positioning platforms on the Web (blogs, websites, etc.), and the hashtag technology as a method of scaling the target audience.

Thus, the behavior of modern youth is influenced by the arsenal of state and non-state media outlets operating in the information field of the Internet. The information policy of many participants in the Internet community is multidirectional, self-interested, and egoistic. In these conditions, young people are far from always being able to discern the real motives of the communicator, as they lack profound knowledge and life experience. As a result of the impact of the media, young people's behavior can take two forms: 1) unconventional behavior: disagreement with the current "agenda" and the information policy of the state, which is later realized in a protest movement; 2) conventional behavior: the loyal behavior of young people, expressed in support of the current authorities and elites.

\section{Results}

\section{Models of media consumption and media behavior of contemporary youth in Russia ${ }^{1}$}

According to the survey, respondents mentioned the Internet (100\%), television (80\%), and people close to them (family) (62\%) as the most relevant channels for obtaining information. However, Internet resources dominate the mechanism of creating impressions and promoting one's own ideas.

Referring to the Internet and social media is not only about finding relevant information. These media act as tools of reputational positioning. Answering the question: "How important is for the respondent the status, prestige, and authority in the society?", the following answers were received: "very important" - 50\%; found it difficult to answer - 20\%; and $30 \%$ do not use them as markers of social positioning. However, in the information society, reputations are a very important component of symbolic capital, giving appeal and popularity among users. Young people often choose a personal image that will distinguish them from other users.

According to the survey, social networks are a window to the media for the majority of respondents. Each reader has 1-2 entry points - pages from which they habitually start reading. A significant number of clicks on internal links indicates that the media is succeeding in keeping a user's attention. For this purpose, social networks are used by $48 \%$ of contextual links to websites $-25 \%$; aggregators $-11 \%$; main page of the media $-8 \%$; messengers $-3 \%$; search $-3 \%$; mail $-2 \%$.

The structure of the sources of information allows us to identify the relevant models of media consumption by different groups of Russian youth.

The "Life on a Feed" model is an active media consumption model. It is based on the social networking feed, although it is not the only source of information, the majority of clicks to publications come from there. This is a "headline" type of information consumption, modern media formulate the headline so that it has a main idea, so people do not even read the essence of the material itself.

\footnotetext{
${ }^{1}$ An empirical study conducted by the authors in June 2020 in the form of a sociological survey on the topic "Models of media consumption in contemporary Russia" among the residents of Moscow on the basis of spontaneous sampling (18-65 years old), the sample size was 1000 people.
} 
The "Monitoring Selected Sources" (Balanced) model: Users receive information from a limited number of selected sources. The reader goes directly to trusted and favorite resources and studies what is new there. This is the most political model since a person with strongly established political views is a follower of specific sources. This type of person often has a maximum of about 10 trusted sources in their arsenal.

The "Watch Everything" (Absorbed) model is characteristic of apolitical people as they use the web for leisure activities. Browsing sources is most often spontaneous.

The predominance of the first and second patterns of media consumption among young audiences correlates with their parents' level of financial standing. For example, if the presidential election were held on the coming Sunday, V.V. Putin would not get $50 \%$ of the votes. Moreover, $25 \%$ of the electorate would not go to the polls or would not decide on a candidate. People with higher incomes would vote for the current head of state. Voters with average incomes were equally divided between supporters and opponents of Putin. People with a low level of income are dominated by a protest mood $-13 \%$.

In recent years the Russian state has created a great variety of information resources: databases, information arrays, arrays of documents. However, insufficient coordination (Gazisov, 2016) of interactions between regional and federal authorities prevented the integration of accumulated knowledge and developed regulations into a single, coherent system. This significantly hindered public access to information resources caused numerous difficulties in the systematization and categorization of information data and information arrays. Paradoxically, the pandemic has contributed to considerable progress in this direction.

\section{The protest representation factors of modern Russian youth}

Although the protests of January 2021 were instigated by foreign agents of influence, they should still be seen as well-known models of positioning the demands of certain segments of the youth audience. The youth audience is split, with an overwhelming majority supporting the political course of Putin.

Along with the notable influence of the Internet and social media on the formation of forms of youth representation, an important role in the formation of protest potential was played by socio-economic conditions, the population's standard of living, the consequences of the COVID-19 pandemic, the presence of transparent channels of communication between the authorities and society, the dominant type of political attitudes among young people, and the predominance of emotional perception due to psychological characteristics of the young age.

The specific nature of the political culture of young people is due to the predominance of irrational components of consciousness due to age. The pressure of emotional factors negates the logical, rational thinking abilities of the youth audience, which is found in the type of thinking, judgments, and ways of making decisions. A key consequence of the prevalence of irrationality is the priority of intuitive behavior and sensual, emotional choices. These factors play a key role in influencing the political consciousness of young people, as they directly influence young people's political decisions: choice of candidate, ideology, and motivation for political participation. In the context of manipulation of political consciousness of youth, appeal to feelings, emotions, and personal values play an important role. For the same reason, the impulsive, emotional rhetoric of gatherings is more effective in influencing political consciousness than a formal press conference. The organizers of the January protests skillfully took advantage of these characteristics of the youth audience by involving them in unsanctioned gatherings.

To a certain extent, the radicalization of public opinion is caused by the decline in the standard of living of the population due to the COVID-19 pandemic. The pandemic has 
transformed everyday lifestyle and changed many social practices, creating fear and panic in society. It has also brought significant financial and social problems to citizens. For a long time, small businesses were without support, and the payments made by the government did not always reach the addressees. For this reason, the doctors of the hospital in Kommunarka had to personally address the head of state through the media to solve the problem of additional payments. There were a lot of controversial actions at the beginning of the pandemic over the measures taken by the authorities to prevent the spread of the infection itself. For example, the lack of measures to prevent coronavirus infection by the management of a Gazprom facility in Yakutia at the end of April 2020 led to a strike by workers and a shutdown of production. At the same time, the news spread quickly on the Internet, while the federal media tried not to talk about it. When society feels voiceless, when the direct demands of the population are not translated into political solutions, people begin to manifest themselves in forms of protest identity. Over the past few years, Russia has adopted several unpopular reforms in society (e.g. pension reforms). In many cases, the growth of protest attitudes is caused by a fall in the trust ratings of state institutions and officials.

A survey of the protest potential of the population conducted by the Levada Centre in June 2020 found that $28 \%$ of citizens were prepared to protest because of falling living standards. This is the highest level in a year and a half. The public with secondary education (Levada-Tsentr, n.d.) (32\%) was the most willing to protest. The youth from 18 to 24 years old $(40 \%)$ were the ones who were most ready to protest. Besides, people between 40 and 54 years $(35 \%)$ would be willing to participate in protests. In Moscow, $26 \%$ of those surveyed would be prepared to participate in mass actions, whereas in rural areas, one-third would. Economic protests were supported by the poorest respondents, who described their level of income as "barely enough to eat" (37\%).

In conditions of a deterioration of the economic situation, a drop in the ratings of public trust in the activity of the state authorities and state officials is evident. Practically all over the world, the role of each social institution has been reconsidered. There has been an increased interest in the activities of NPOs, whose ethical stance appears to be advantageous. In these circumstances, the leaders of the non-profit sector are keen to use their perceived 'moral authority' for political purposes. Indeed, these leaders and their sponsors often use techniques to directly defame the leaders of the state for this purpose. This was the case with the blogger A. Navalny's "Anti-Corruption Foundation", who produced a fake film called "Putin's Palace" based on a German campaign commissioned by the US.

The Western sanctions regime and the impact of the pandemic have increased the proportion of citizens who believe the country is heading in the wrong direction. The data presented by the leading Russian sociological surveys that reflect the index of protest moods in the country before the self-imposed regime was announced (February 2020) and its actual easing in most regions (May 12, 2020) are illustrative: VTsIOM - 28\% and 33\%; the Foundation "Public Opinion" - 29\% and 34\%; Levada Center - 29\% and 34\%. Although during the pandemic, surveys were conducted by telephone, we can see the dynamics of the growth of protest potential in Russia.

The population's adaptation to the realities of life in the crisis is not easy. According to a VTsIOM survey (September 2020) on "Social well-being of Russians" according to the parameters: 1) the Russians' self-assessment of their financial situation; 2) the life satisfaction index; 3) the social optimism index. Compared to August 2020, 60\% of Russians assess their family's material standing predominantly as average $(60 \%)$. The number of negative assessments has decreased by 2 p.p. and amounted to $24 \% .15 \%$ of Russians estimate the material standing of their family as good. Russians are rather satisfied with their lives. $46 \%$ reported that they are completely satisfied with the life they have, another $30 \%$ stated that they are partially satisfied and partially not. Total dissatisfaction with their lives was reported by $23 \%$ of Russians, which is 2 p.p. lower than in September last year. The life satisfaction index 
made up $53 \mathrm{p}$. The social optimism index made up 61 p., i.e. remained at the level of JuneAugust 2020, and, after the spring fall, rose to -81 p. in April. More than half of Russians believe that the economic crisis is yet to come (60\%). However, $15 \%$ believe that the worst is now and $16 \%$ believe that it is over (Sotsialnoe samochuvstvie rossiyan: monitoring, n.d.). The problems of rising prices, massive cuts (especially during the pandemic), social tensions, growing inequality between the rich and the poor (the middle class is decreasing too), enterprise closures due to the pandemic, adoption of unpopular reforms in society, etc. should be solved by the state authorities together with the civil society. However, in practice, it is not always possible to realize society's demands promptly, which leads to protest positioning.

\section{Conclusion}

1. The Internet is the most sought-after source of not only political but also any new information, which has a high level of trust among young audiences, compared to traditional media (television, radio broadcasting, and paper press), which are now becoming secondary. For young people, they have a low "informing" effect, with very little credibility, especially for political information.

2. Modern Russian youth is highly involved in the virtual space, which causes the processes of political communication and socialization, the formation of the political culture in the online environment. The maturation of personal "value matrices" (attitudes, beliefs, views), political consciousness, models of political behavior, evaluations in relation to certain political actors and events takes place on the Internet.

3. The modern Internet, while providing an enormous amount of information, simultaneously constructs a social reality, which often differs from the political agenda shaped by the authorities. Ignoring those needs that do exist in society generates a surge of protest attitudes in the youth audience, which feels this discrepancy most keenly and reacts emotionally to them.

4. The poor critical thinking of young audiences often turns them into "obedient instruments" in the capable hands of domestic and foreign "puppeteers". This circumstance does not take away responsibility from young people who, in the pursuit of hype and spectacle, often do not think about forms of constructive self-determination. The dominance of entertainment at schools and universities over the content of contemporary education does not allow for the formation of a critical view of reality and the setting of clear priorities in the life of young people, which would be consistent with their mission as subjects building the future of their country.

\section{Referencias}

Almond, G., Powell, B. (1966). Comparative Politics: ADevelopmental Approach. Boston: Little, Brown.

Baudrillard, J. (1999). Sistema veshchei [The System of Objects]. Moscow: Rudomir.

Gazisov, R.R. (2016). Politicheskaya problematika v sovremennoi mediapraktike [Political issues in contemporary media practice]. Fundamentalnye i prikladnye issledovaniya $\mathrm{v}$ sovremennom mire [Fundamental and applied studies in the modern world], 13-4: $122-130$.

Griffin, E. (2015). Kommunikatsiya: teorii i praktiki [Communication: theories and practices]. Kharkiv: Izd-vo «Gumanitarnyi Tsentr».

Levada-Tsentr. (n.d.). Retrieved from: https://www.levada.ru/

Mukhaev, R.T. (2020). Mediapolitika: Uchebnik [Media policy: Textbook]. Moscow: INFRA-M. 
Rumin, I. (2010). Informatsiya i obshchestvennoe mnenie: ot reportazha v SMI k realnym peremenam [Information and public opinion: from media reports to real changes]. Moscow: Alpina Pablisherz.

Savin, L.V. (2013). Kouching voina. Vzglyad na konflikty s tochki zreniya menedzhmenta [The coaching war. A look at conflicts from a management perspective]. Informatsionnye voiny [Information wars], 4: 78.

Smirnov, S. (January 24, 2021). «Polnaya protivopolozhnost Putinu»: mirovye SMI i politiki o Navalnom i protestakh v Rossii ["The complete opposite of Putin": global media and politicians on Navalny and the protests in Russia]. The Bell. Retrieved from: https://thebell.io/polnaya-protivopolozhnost-putinu-mirovye-smi-i-politiki-onavalnom-i-protestah-v-rossii

Sotsialnoe samochuvstvie rossiyan: monitoring [Social well-being of Russians: monitoring]. (n.d.). WCIOM. Retrieved from: https://wciom.ru/analytical-reviews/analiticheskiiobzor/soczialnoe-samochuvstvie-rossiyan-monitoring 